important extension to this building, which completes the scheme, was formally opened on March 16 by Mr. W. D. Woolley, chairman of the Monmouthshire and South Wales Coalowners' Association. The new accommodation provides: ground floor, mechanical laboratory, physical laboratory and leeture room ; first floor, three research laboratories, private room, museum and library; second floor, chemical laboratory, balance room, combustion and gas analysis, laboratory and private room. The College has now a well-planned and well-equipped building for teaching and research work, the erection of which is due to the generosity of the Monmouthshire and South Wales Coalowners' Association.

\section{Projected Flight over Everest}

Is our issue of February 4 (p. 160), reference was made to the two aeroplanes which have been modified to undertake a flight over Mount Everest. According to the Karachi correspondent of the Times, the machines arrived at Karachi on March 9. The main base for the expedition will be Purnea. The photographic results of the flight, should it be successful, are likely to be of considerable interest, for nothing is known at present of the south face of Everest. Indeed, if the photographs are available in time, they may be of assistance to the expedition now in India preparing to climb the mountain (NATURE, Jan. 7, p. 10), especially if the snow and ice conditions have changed considerably since the 1924 expedition. Useful data may also be obtained of atmospheric conditions; while we know a good deal about the atmosphere at $30,000 \mathrm{ft}$. above mean sea level, it is likely that conditions at this absolute height but with high mountains below will be different. The aeroplanes, however, are not suited for making useful cosmic ray observations. The flight will be a great adventure, for should the machines have to come down through engine failure, the chances of finding a suitable landing place in that great area of mountainous country are small.

\section{Discovery of Sexuality in Plants}

THE discovery of sex in plants is usually credited to Camerarius (1694), and Koelreuter (1761) is generally believed to have made the first systematic study of plant hybrids. Statements of Sachs in his "History of Botany" are mainly responsible for these attributions. Dr. Conway Zirkle is able to show, however ( $J$. Hered, vol. 23, No. 11), that other names really have priority in connexion with these important developments in the history of science. N. Grew, in an address to the Royal Society in 1676 , expressed the view that the stamens are the male organs of a flower, the pollen acting as vegetable sperm. Thomas Fairchild, whom Sachs referred to as "a gardener in London", was in fact the leading experimenter of his generation, and his famous cross between sweet william and the carnation is shown to have been made at least as early as 1717. Philip Miller was the first to describe insect pollination by observations on tulips. This was not, however, in 1751, as stated by Sachs, but so early as 1721. He also observed natural crossing in cabbages as well as sexual reproduction in cucumbers and melons. Dr. Zirkle also gives an interesting account of equally early American observations on pollination and crossing, chiefly in maize, by Cotton Mather (1716), Judge Dudley (1724) and Governor Logan (1735). A letter of John Bartram in 1739 shows that he too had made species crosses in Lychnis at that date.

\section{Courtship of Birds}

THE courtship displays of birds, wherein they manifest the amorous emotions which possess them, are now daily becoming more and more assertive. Much has yet to be learned concerning the 'behaviour' of birds thus possessed at this time; and the relation of this behaviour to various and often conspicuously coloured plumage, wattles, bare skin, or inflatable air-sacs. The pheasants afford striking illustrations of apparently conscious effort to display such orna. ments to the best advantage before apparently disinterested females. The belief that these displays serve as aphrodisiacs must be regarded as wellfounded. This fascinating aspect of bird life can now be studied at the Zoological Gardens, Regent's Park ; a number of tragopans, or horned-pheasants, as well as Cheer, Impeyan, and Kalij-pheasants, having just been added to the collections. Blyth's tragopan from Assam, and the crimson tragopan from the south-eastern Himalayas, each bears an erectile appendage over the eye, of a vivid blue colour; and an inflatable wattle at the throat. In Blyth's tragopan this is yellow tinged with blue, while in the crimson tragopan it is orange, barred with blue, and when filled with air presents a strange effect. If the courting antics of the tragopans be compared with those of the golden and Amherst pheasants, wherein the chief ornaments take the form of a great frill of vividly coloured feathers encircling the neck, the contention that both types display deliberate and purposeful movements designed to make the most effective possible use of these ornaments will seem incontrovertible. Though the Darwinian view that these resplendent areas were brought to perfection by the selective preferences of the female, before whom they are displayed, has lost its hold, they are nevertheless instances of 'sexual selection'; since only the most amorous males, the most skilled performers, can succeed in arousing the desired response in their phlegmatic prospective mates.

\section{Vanished Races in South Africa}

From time to time news is received of the discovery in South Africa of a new and previously unknown culture, presumed to be the work of a vanished race. More often than not the finds are associated with stone-work or the evidence of metal-working. The latest discovery to be reported (Times, March 13) comes from the northern Transvaal, where $\mathrm{Mr}$. D. S. van der Merwe, assistant registrar of mining titles on the Rand, has discovered sacrificial graves of an entirely new type, a sacrificial altar, approached by ceremonial causeways and by staircases, an 
irrigation system of enormous extent, together with the remnants of a large dam. There is also a copper tool, which is said to be an authentic mining imple. ment. These finds are ascribed to a vanished race, and on account of the diminutive size of the stairways, it is suggested that its members were pygmies. The collections have been placed at the disposal of the Ethnological Department of the University of the Witwatersrand and are said to be regarded by the Department as very important. As Mr. van der Merwe is a layman in ethnological matters, the verdict of experts in the cultures of the natives of South Africa will be awaited with interest. As a rule, unfortunately, previous claims to the discovery of new cultures and vanished races have not survived their impartial scrutiny.

\section{A New South African Culture?}

A ClAIM to have distinguished a new material culture in South Africa is put forward by Dr. Ir. E. C. N. Van Hoepen, director of the National Museum, Bloemfontein (Argoeologiese Navorsing, Dl. i St. 5), in describing a remarkable stone pipe from a shelter near Bethlehem. Its peculiarity lies in the ornamentation, a system of curved grooves and on one side a sinuous ridge ending in a reversed $\mathrm{E}$, representing a snake. Similar pipes have previously been described, one of clay from the ash-heaps of stone huts at Vegkop by Van Riet Lowe and another of stone by Stow. Van Riet Lowe attributed the pipe he described to the Leghoya, dating the huts at about 1790, but Dr. Van Hoepen does not consider his reasoning or evidence satisfactory, and points out that stone huts are not a characteristic of Bantu culture, the Leghoya themselves using conical grass thatched huts, according to Stow. He himself sees in the pipes and the shelters closer affinities with Hottentot, Bushmen, and Xosa, but concludes that the three characters, the stone pipes, the stone huts and the ornamentation do not belong to any known African culture. We are, therefore, he holds, dealing with something new, a culture for which the name 'stone-hut' culture is proposed. This view, important as it is for the history of South African cultures, should be accepted with some caution. Its confirmation by further evidence will be awaited with interest.

\section{American Archæologists in Yugoslavia}

AT a meeting of the American Anthropological Association held in Atlantic City at the end of December, Dr. Vladimir J. Fewkes described the work during the past summer of a joint archæological expedition of the Peabody Museum, the Fogg Art Museum, Harvard University, and the American School of Prehistoric Research in Jugoslavia. Some 150 archæological sites were visited and examined. A large proportion of these were found to belong to Greek, Roman, Macedonian or Byzantine cultures. The most considerable undertaking of the expedition was the excavation of the neolithic site at Starcevo, of which the investigation had been begun in the previous year. The settlement is dated at about 2500 B.C. and is found to consist of a number of irregularly placed groups of semi-subterranean dwel. lings, of which the foundations have been exposed. Among the material found are crude but well-made cooking pots, painted pottery, needles, awls and spatulas of bone, stone knives and celts, shells, and small libation tables of baked clay. The settlement was one of small farmers with domesticated animals, who supplemented their food supply by hunting and fishing. In a report of the communication from Science Service, Washington, D.C., Dr. Fewkes is said to have stated that the expedition had gathered fresh evidence relating to the early trade routes of this part of Europe, an area he regards as the archæological key-region of the Balkans.

\section{Spectrum Analysis}

THE increasingly great interest now being shown in spectrum analysis is well exemplified by two recent developments in the United States. The first of these was the setting up by the American Society for Testing Materials of a committee (E-2) on spectrographic analysis in its application to analytical and metallurgical problems. This committee is now at work and it is probable that tangible results will be forthcoming in the near future. News of the second development has just reached Great Britain. It has been decided that one of the lines of work to be intensively pursued at the magnificently equipped spectroscopic laboratory of the Massachusetts Institute of Technology is the application of spectrum analysis to industrial and related problems. In order that as close touch as is possible may be made with industrial problems, a research conference is to be held at the Institute during the week beginning July 17, and it is hoped that at this conference industrial experts, academic research workers and manufacturers of spectroscopic equip. ment will meet and discuss those aspects of the problem with which they are individually familiar. It is clear that one of the earliest developed aspects of spectroscopy is again coming very much to the fore, and that the dreams of some of the early spectroscopists regarding the general use of this technique in industry are coming measurably nearer realisation.

\section{Machine Age's Starvation Predicted}

THE comparatively rapid depletion of the earth's available resources in this mechanical age was considered by Prof. R. A. Gortner, of the University of Minnesota, in a paper before the American Association for the Advancement of Science in December (Science Service, Washington, D.C.). It is pointed out that irreplaceable stores of natural resources absolutely essential to modern industrial civilisation are disappearing into the 'maws of industry' and so are wastefully dissipated over the earth. While the publicity of technocracy directs attention to the part played by mechanical energy in remaking economic conditions, the shelves in some of Nature's cupboard are showing signs of exhaustion of the materials necessary for a mechanical age. In particular, Prof. Gortner mentions the approaching exhaustion of copper, antimony, tin, lead, zinc, chromium, manganese, nickel and iron, which are stored in parts 